\title{
Compressibility behavior of Boron (Tincal) added to sand- bentonite mixtures under different temperatures
}

\author{
Sukran Gizem Alpaydin ${ }^{1, *}$, and Yeliz Yukselen-Aksoy ${ }^{2}$ \\ ${ }^{1}$ Dokuz Eylul University, The Graduate School of Natural and Applied Sciences, Geotechnics Department, 35390 Izmir, Turkey \\ ${ }^{2}$ Dokuz Eylul University, Department of Civil Engineering, 35390 Izmir, Turkey
}

\begin{abstract}
The importance of thermal behaviour of soils has increased significantly with increasing number of energy structures. There is a need for soils, which show design criteria (strength, permeability, etc.) performance during their life under high temperature or thermal cycles. In the literature studies, it was observed that the volumetric deformation of the soil changes with increasing temperature. Sand-bentonite mixtures generally act as impervious barrier in areas such as nuclear waste repositories, landfill liners etc. These mixtures will be exposed to high temperature; therefore, their engineering performance should not alter under high temperature. Boron is used in the industry for high temperature resistance, flexibility, lightness, power and ease of production. Boron minerals have very low thermal expansion and they are also resistant to thermal shocks. For that reason, the properties of sand-bentonite mixtures can be improved by boron additives at high temperatures. In this study, volume deformation behavior of sand-bentonite mixtures was determined in the presence of tincal. The oedometer tests were performed under room temperature and $80^{\circ} \mathrm{C}$.
\end{abstract}

\section{Introduction}

A thorough understanding of the effect of temperature on the hydraulic and mechanical behavior of soils is crucial for many engineering applications. Especially the soils which are surrounding energy structures and used as impermeable barriers in nuclear and solid waste repositories, are exposed to high temperatures and thermal cycles. The engineering properties of these soils can be adversely affected as a result of temperature changes.

Bentonite or sand-bentonite mixtures are generally used as impermeable barriers in waste repositories. According to the previous studies in the literature, it has been reported that hydraulic conductivity, volumetric deformation, shear strength properties of such soils change at high temperatures $[1,2]$. The resistance of fabric changes against temperature is explained with clay interparticle forces and viscous shear resistance of adsorbed water [3].

The impact of temperature on the volume deformation behaviour of a soil depends on its overconsolidation ratio, plasticity, expansibility and compaction water content [4]. Recordon (1993) performed thermal consolidation tests on fine sand samples under temperatures between $2^{\circ} \mathrm{C}$ and $40^{\circ} \mathrm{C}$. It was observed that compression index and overconsolidation ratio of sand samples were independent of temperature [5]. In another study, it was shown that the compression index $\left(\mathrm{C}_{\mathrm{c}}\right)$ of bentonite increased with increasing temperature [6]. According to results of this study, the volumetric compression coefficient $\left(\mathrm{m}_{\mathrm{v}}\right)$ decrease with increasing consolidation pressure but it was not affected by temperature. The volume change results from the discharge of water and steam from the sample, the particle movement of the particles induced by vapor pressure, and physical and chemical reactions such as solid particle breakage and organic decomposition [7]. In the study of Abuel-Naga et al., (2006), soft Bangkok clay was heated up to $90^{\circ} \mathrm{C}$ by heating the water in the consolidation cell. It was observed that the change in the void ratio depends on the stress history, however; it is independent from the magnitude of the stress applied under high temperatures. The compressibility behavior of Bangkok clay was also influenced by the heating-cooling cycles. The normally consolidated Bangkok clay began to exhibit an overconsolidated clay behavior due to increased temperature. In addition, in this study, it was reported that normally consolidated clays contracted irreversibly and nonlinearly due to high temperature in terms of volumetric strain [1]. However; highly over consolidated clays may even show volume expansion when temperature was increased $[8,9]$. Towhata et al. (1993) interpreted the contraction as thermal deterioration of clay skeleton due to heating, expansion is attributed to the thermal expansion of the pore water, which causes the soil skeleton to swell [10].-In another study volumetric deformation behavior of cohesive sediments under high temperature is observed by Dalla Santa et al., (2016). In this study, cohesive sediment samples were tested by heating up to $50^{\circ} \mathrm{C}$ with water in the oedometer

\footnotetext{
* Corresponding author: gizem.alpaydin@gmail.com
} 
cell. According to the results, sediments showed a permanent deformation of $9.3 \%$ with rising temperature [11]. A decrease in the volume of compacted sandbentonite mixture with increasing temperature from $25^{\circ} \mathrm{C}$ to $90^{\circ} \mathrm{C}$ has been reported by Shariatmadari and Saeidijam (2011). In addition, it was reported that the time required for stabilization at high temperature is less due to increased permeability with high temperature [12]. One of the rare studies on soil mixture instead of one type of soil is the study of Sinha \& Kusakabe (2008), on the volumetric change of sand-bentonite mixtures against high temperature. In this study, 10\% bentonite- $90 \%$ sand mixture was heated up to $75^{\circ} \mathrm{C}$ and volumetric strain behavior was observed. In $\mathrm{NC}$ conditions, the pore water pressure changes depending on temperature, and therefore the void ratio changes. It was determined that the increase in heat caused an increase in the amount of volumetric strain. In other words, higher temperature was more effective in changing the volume in NC condition. In the experimental results, when the temperature was rised from $20^{\circ} \mathrm{C}$ to $45^{\circ} \mathrm{C}$, the strain increased $0.37 \%$ and when the temperature increased from $20^{\circ} \mathrm{C}$ to $75^{\circ} \mathrm{C}$ the strain increased to $0.51 \%$ [13].

Additives can be added to bentonite or sandbentonite mixtures to reverse the negative effects of high temperatures. Boron may be suitable as an additive because its high resistance to temperature and low thermal expansion property. Also, boron minerals increase thermal stability and prevent radiation transmission [14]. In borosilicate glass production, boron additive increases mechanical strength and resistance against thermal shocks [15]. In addition, boron provides high temperature resistance in glass. Boron is also used in nuclear power plants as a neutron absorbing material. The boron is held strongly by the aluminum or silicon tetrahedron portion in the clay structure [16]. Among illite, montmorillonite and kaolin minerals, the highest boron adsorption done by illite and the least adsorption done by kaolinite. Yet because the surface area of montmorillonite is higher than illite, it is accepted that montmorillonite can adsorb as much boron as illite [17]. Boron does not exist freely on earth. Instead, it bonds with oxygen and various elements and takes place in mineral form in nature, such as; colemanite, tincal, ulexite etc. Tincal was used as additive for this study. Tincal, which is a boron mineral, was preferred because it is resistant to temperature changes as mentioned, because it may the potential to protect the properties of the soil by adding it to the soil at high temperature. In this study, the change of compressibility under high temperature $\left(80^{\circ} \mathrm{C}\right)$ was investigated by adding tincal to the sand-bentonite mixtures.

\section{Materials and Methods}

\subsection{Materials}

Na-bentonite sample used in this study was gathered from Eczacıbașı Esan Mining Company. The sand used was classified as well-graded sand (SW) according to
Unified Soil Classification System (USCS) and the grain size distribution is given in Figure 1 [18].

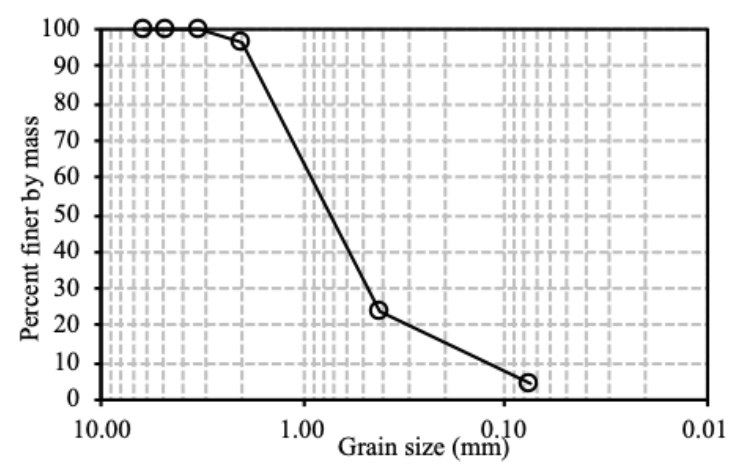

Fig. 1. Grain size distribution of sand

Tincal, a boron mineral, added as an additive to sandbentonite mixtures, was supplied from Eti Maden Operations General Directorate of Turkey. The chemical formula of tincal mineral is $\mathrm{Na}_{2} \mathrm{~B}_{4} \mathrm{O}_{7} \cdot 10 \mathrm{H}_{2} \mathrm{O}$. The physico-chemical properties of the materials are shown in Table 1.

Table 1. Physico-chemical properties of the materials.

\begin{tabular}{|c|c|c|c|}
\hline & Bentonite & Sand & Tincal \\
\hline Specific Gravity & 2.70 & 2.63 & 1.67 \\
\hline Liquid Limit (\%) & 476 & - & 61 \\
\hline Plastic Limit (\%) & 70 & - & 43 \\
\hline Plasticity Index (\%) & 406 & - & 18 \\
\hline $\mathrm{pH}$ & 9.50 & - & 9.12 \\
\hline
\end{tabular}

\subsection{Methods}

\subsubsection{Sample Preparation}

While preparing the mixtures, sand and bentonite were dried in the oven $\left(105^{\circ} \mathrm{C}\right)$. Then sand and bentonite were sieved through No.6 and No.200 meshes, respectively. Tincal was used in its natural form without being dried. Because it was observed that its structure changed when it was left for drying in the oven. Tincal was first crushed with jaw crusher and then sieved through No.40. While preparing the mixtures, the natural water content of tincal was determined and taken into consideration in the calculations. While preparing the mixtures for the tests, $10 \%$ or $20 \%$ of the dry mixture was taken as tincal. Then, $10 \%$ or $20 \%$ of the remaining mixture was taken as bentonite and the remaining amount was composed of sand. The mixtures are named according to the first letter of the materials and the percentage in the mixture. For example, the mixture of 10T-9B-81S consists of $10 \%$ tincal, $9 \%$ bentonite and $81 \%$ sand. 


\subsubsection{Experimental Methods}

Consolidation tests were carried out according to with the ASTM D2435 standard [19]. For the consolidation tests, samples were prepared on the $2 \%$ wet side of the optimum water content, which previously determined by the Standard Proctor test and at the dry unit weight value corresponding to this water content. The prepared sample was compacted into three layers with a wooden hammer and placed into the ring. The ring was placed in a cell filled with water and seating pressure $(6.86 \mathrm{kPa})$ was applied for 24 hours. Then the loading was started. When the deformations reached a negligible level, the next loading was started. Load increment ratio (LIR) was applied as 1.0. The odeometer was assembled with hard steel disk of approximately the same height as the test specimen for calibration at the beginning of the tests. In addition to room temperature tests, specially designed heat rod and thermostat system were placed in each odeometer cell for high temperature $\left(80^{\circ} \mathrm{C}\right)$ tests. Thanks to the heat rod, the sample was heated with increasing water temperature (this stage was performed after the seating pressure stage). The thermostat system controlled the temperature inside the system and keep at constant temperature. In addition, each cell was covered with a rubber membrane to minimize evaporation during the tests. Nevertheless, since the evaporation continues through the openings, a very low flow of water was provided to the cells from the water tank continuously. Flow rate was $1 \mathrm{ml} / \mathrm{min}$ in order to keep the water level constant in the cell. Thanks to the rapid heating power of the heat rod, this flow rate did not cause fluctuations in the temperature of the water. In addition, the temperatures of the water and the sample were measured continuously with K-type thermocouples connected to the digital thermometer, so it was confirmed that the temperature was $80 \pm 2^{\circ} \mathrm{C}$ and did not change. During the tests, the temperature was measured continuously by digital thermometers.

\section{Results}

In this study, $10 \%$ and $20 \%$ tincal was added to sandbentonite mixtures and odeometer tests were performed. The tests were carried out on the identically prepared samples under room temperature $\left(22 \pm 2^{\circ} \mathrm{C}\right)$ and $80^{\circ} \mathrm{C}$ and the results were compared. The results were compared under the same vertical effective stress $(98.1 \mathrm{kPa})$. The stress-strain curves of sand-bentonite mixtures in the presence of tincal are given in Figure 2. Also, Table 2 presents total vertical compression percentages of all mixtures at room temperature and $80^{\circ} \mathrm{C}$.

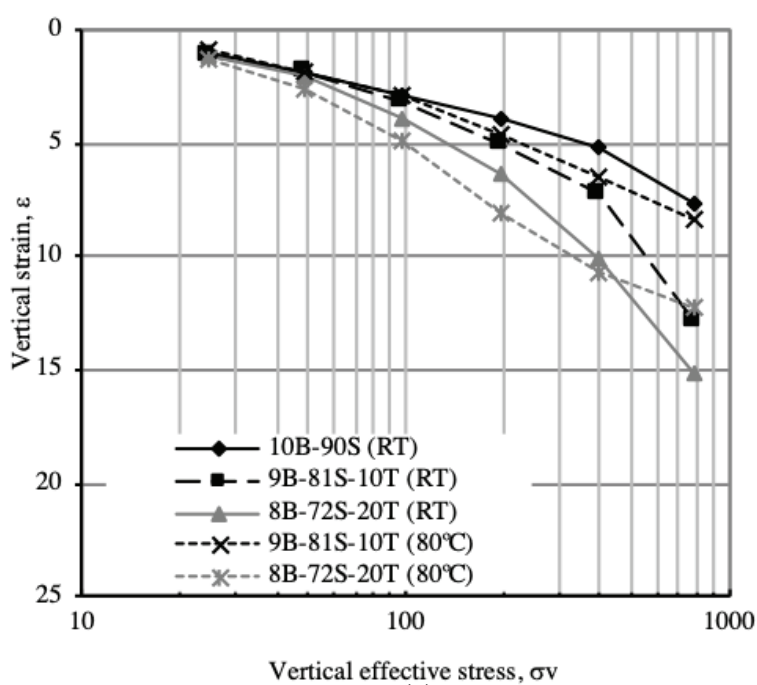

(a)

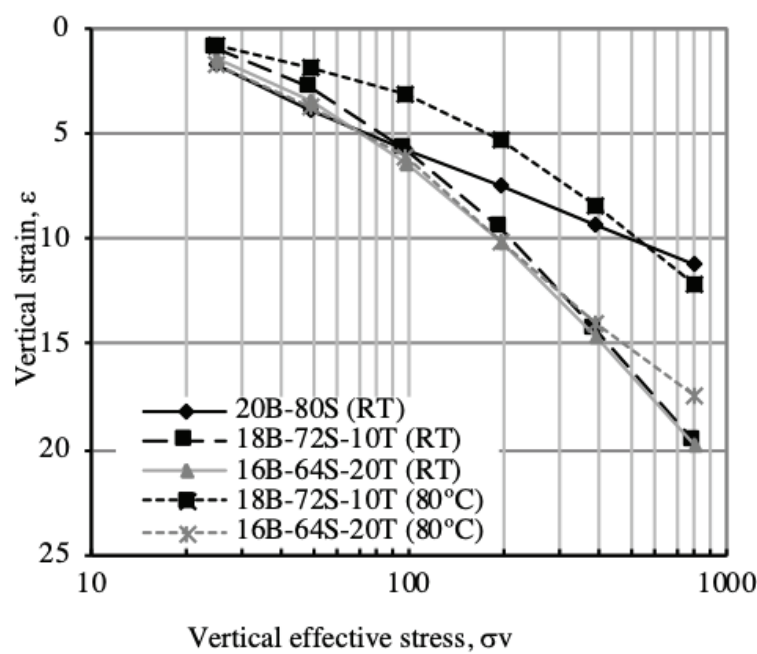

(b)

Fig. 2. Stress-strain curves mixtures of a)10B-90S, b) 20B-80S

According to the Table 2, the deformation amount of $10 \mathrm{~B}-90 \mathrm{~S}$, which was $6.58 \%$, increased by $5.14 \%$ with $10 \%$ tincal additive at room temperature. When the tincal amount was increased from $10 \%$ to $20 \%$, the deformation increased by $2.3 \%$ and reached to $14.0 \%$. It was observed that the tincal additive increased the compression amount of the $10 \%$ sand-bentonite mixture at room temperature. For $20 \%$ sand bentonite mixtures, the compression amounts reached from $9.5 \%$ to around $18 \%$ with tincal additives at room temperature. When the tincal added mixtures were heated to $80^{\circ} \mathrm{C}$, compression amounts of these mixtures decreased by about $3 \%$. When the temperature increased to $80^{\circ} \mathrm{C}$, the compression amounts of tincal added $20 \%$ sand-bentonite mixtures decreased similar to tincal added $10 \%$ sand-bentonite mixtures. 
Table 2. Total vertical compression of all mixtures.

\begin{tabular}{|c|c|c|c|}
\hline \multirow{8}{*}{ 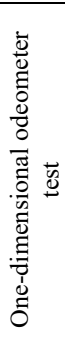 } & \multirow[b]{2}{*}{ Sample } & \multicolumn{2}{|c|}{ Total vertical strain (\%) } \\
\hline & & $\begin{array}{c}\text { Room } \\
\text { Temperature }\end{array}$ & $80^{\circ} \mathrm{C}$ \\
\hline & 10B-90S & 6.58 & - \\
\hline & 9B-81S-10T & 11.72 & 7.42 \\
\hline & 8B-72S-20T & 13.98 & 10.98 \\
\hline & 20B-80S & 9.53 & - \\
\hline & 18B-72S-10T & 18.70 & 11.37 \\
\hline & 16B-64S-20T & 18.34 & 15.76 \\
\hline
\end{tabular}

The compression index $\left(\mathrm{C}_{\mathrm{c}}\right)$ and volumetric compression coefficient $\left(\mathrm{m}_{\mathrm{v}}\right)$ values of the all samples are seen in Table 3 at both temperatures. The $\mathrm{C}_{\mathrm{c}}$ values of $10 \%$ sand-bentonite mixtures with tincal addition decreased by half with increasing temperature.

Table 3. Compression index and volumetric compression coefficient values of all samples at both temperatures.

\begin{tabular}{|l|c|c|c|c|}
\hline \multirow{2}{*}{ Sample } & \multicolumn{2}{|c|}{$\begin{array}{c}\text { Compression index } \\
\left(\mathrm{C}_{\mathrm{c}}\right)\end{array}$} & $\begin{array}{c}\text { Volumetric compression } \\
\text { coefficient }\left(\mathrm{m}_{\mathrm{v}}\right) \\
\left(\mathrm{cm}^{2} / \mathrm{kg}\right)\end{array}$ \\
\cline { 2 - 5 } & $\begin{array}{c}\text { Room } \\
\text { Temperature }\end{array}$ & $80^{\circ} \mathrm{C}$ & $\begin{array}{c}\text { Room } \\
\text { Temperature }\end{array}$ & $80^{\circ} \mathrm{C}$ \\
\hline 10B-90S & 0.118 & - & 0.011 & - \\
\hline 9B-81S-10T & 0.201 & 0.106 & 0.013 & 0.011 \\
\hline 8B-72S-20T & 0.262 & 0.133 & 0.018 & 0.025 \\
\hline 20B-80S & 0.100 & - & 0.020 & - \\
\hline 18B-72S-10T & 0.301 & 0.203 & 0.032 & 0.012 \\
\hline 16B-64S-20T & 0.311 & 0.236 & 0.030 & 0.025 \\
\hline
\end{tabular}

On the other hand, $\mathrm{m}_{\mathrm{v}}$ values of sand-bentonite mixtures in the presence of tincal tend to decrease with increasing temperature. The compressibility amount of the mixtures decreased at high temperatures thanks to the effect of the fabric change with increasing temperature and by adding the tincal having very low thermal expansion. The thermal expansion coefficient of tincal $\left(0.0000083^{\circ} \mathrm{C}^{-1}\right)$ is quite low compared to bentonite $\left(0.0002^{\circ} \mathrm{C}^{-1}\right)$. Therefore, tincal is not significantly affected by high temperature. Material displacement occurred while preparing the mixtures. In other words, the amount of bentonite and sand was reduced as much as the amount of tincal added to the mixture. Thanks to the resistance of tincal to high temperature, consolidation settlements decreased with high temperature.

\section{Conclusions}

In many engineering projects, the soil is exposed to high temperature and thermal cycles. Generally, the engineering properties of soils can be affected negatively. For example, the high temperatures cause increase in compressibility of clayey soils. It is very important to protect mechanical and hydraulic properties of the soils against temperature changes. In this study, tincal, boron mineral, was added to sand-bentonite mixtures and consolidation tests were performed. The total vertical compressibility of sand-bentonite mixtures in the presence of tincal were investigated at room temperature and $80^{\circ} \mathrm{C}$. Considering the change in compressibility behavior of these mixtures with increasing temperature, the following results were obtained:

- Tincal additive increased vertical compression amounts of sand-bentonite mixtures at room temperature.

- Increased temperature caused a decrease in compressibility of the mixtures in the presence of tincal.

- Also, $\mathrm{C}_{\mathrm{c}}$ and $\mathrm{m}_{\mathrm{v}}$ values generally decreased in the presence of tincal when the temperature was increased to $80^{\circ} \mathrm{C}$.

According to the results of this study, sand-bentonite mixtures in the presence of tincal showed promising behavior in terms of compressibility behavior under high temperatures.

This study is supported by The Scientific and Technological Research Council of Turkey (TÜBİTAK) (Grant no. 217M553). The authors are grateful for this support.

\section{References}

1. H. M. Abuel-Naga, D. T. Bergado, G.V. Ramana, L. Grino, P. Rujivipat, Y. Thet, J. of Geotech. and Geoenv. Eng. 132(7), 902-910 (2006)

2. R. Pusch, O. Karlnland, H. Hokmark, (SKB Technical Report 90-43, Stockholm, Sweden. 1990)

3. H. M. Abuel-Naga, D. T. Bergado, B. F. Lim, Soils Found. 47, 423-436 (2007)

4. M. V. Villar, A. Lloret, Elsevier Geo-Engineering B. Ser. 2, 305-310 (2004)

5. E. Recordon, Rev. Française de Géotechnique (1993)

6. R. Bag, A. Rabbani, Appl. Clay Sci. 136, 1-7 (2017)

7. Z. Chen, H. Zhu, Z. Yan, L. Zhao, Y. Shen, A. Misra, Eng. Geol. 204, 14-22 (2016)

8. G. Baldi, T. Hueckel, R. Pellegrini, Can. Geotech. J. 25 (4), 807-825 (1988)

9. E. Romero, M.V. Villar, A. Lloret, (Proc. $6^{\text {th }}$ Int. Workshop Key Issues in Waste Isolation Research. ENPC, Paris, 28- 30 November 2001)

10. I. Towhata, P. Kuntiwattanakul, I. Seko, Soils Found. 33, 170-183 (1993)

11. G. Dalla Santa, A. Galgaro, F. Tateo, S. Cola, Eng. Geol. 202, 143-152 (2016)

12. N. Shariatmadari, S. Saeidijam, Int. J. Civ. Eng. 10(2), 162-167 (2012)

13. A. N. Sinha, O. Kusakabe, Aust. Geomech. 43, 7586 (2008)

14. G. Guzel, O. Sivrikaya, H. Deveci, (Compos. Part B: Eng. 2016)

15. I. Sugozu, I. Mutlu, K. B. Sugozu,. Polym. Compos 39(1), 55-62 (2016)

16. K. Privett, J.E. Gillott, (Developments in Geotech. Eng., 41. 1987) 
17. R. Keren, U. Mezuman, Clay and Clays Miner. 29, 198-204 (1981)

18. ASTM D2487-17 ASTM Int. West Conshohocken, PA, USA, 1-10 (2017)

19. ASTM D2435/D2435M-11 ASTM Int. West Conshohocken, PA, USA (2011) 